\title{
A patient's diary: episode 23 - My metamorphosis
}

When I woke this morning after a night full of uneasy dreams I found that I had been transformed into an enormous insect! My back was all hard as if armour plated and my mouth had several sets of jaws. And when I looked down I could see that I now had a great round belly divided into segments. Then instead of my normal limbs I had all these horrid little legs (I couldn't even count them I was so upset) just waving to and fro pathetically. I remember thinking, that with so many legs, I am not strictly speaking, an insect which has only six legs, but some sort of earwig or woodlouse. Then I thought, this whole thing is ridiculous, it has to be a dream I must be still asleep. If I just turn over, the illusion will fade and everything will be back to normal. But when I tried to turn over I found I couldn't because of the convex shape of my back. All I could do was rock slightly to and fro. This disturbed Hilda, who woke up and said 'For Heaven's Sake Norman what is it now? Where did you get those pyjamas?' I tried to tell her it was a dream and she should just go back to sleep but I couldn't get the words out properly because I had an insect's mouth.

I tried pinching myself but that didn't work either because although two of my legs are like pincers, I couldn't get them to pinch. By this time Hilda was out of bed, leaning over me anxiously and trying to ascertain what had happened. She said something about the glucosamine capsules I have been taking from the health food shop in the High Street. I warned you to be careful, she moaned. But I don't think the glucosamine could really have done it. What ever it was, it was becoming clear that it was no dream. And the immediate problem was that if I didn't get out of bed soon I was going to be late for work. I looked at the alarm clock: it was already 9.30! Soon my boss, old Ferguson would be ringing to see where I was. I said as much to Hilda but she just looked at me and wailed something before dashing out of the room. With a huge effort, I began rocking myself from side to side and eventually managed to fall out of bed and upend myself against the chest of drawers. Then I let my front rest on the back of the chair and gradually slipped forward till my legs made contact with the ground. To my joy I found I could walk, my little legs coordinating perfectly.

By the time I reached the kitchen, Hilda was already on the phone to the surgery. I could hear her asking for a home visit. She was being put through the usual interrogation you get nowadays. I believe it's called 'Triage'. 'Yes, an insect,' she was shouting (which is quite unlike her usual calm manner) 'no of course it hasn't happened before. And it isn't a rash and I don't know if he has a temperature. Come to the surgery? How can he come to the surgery on all those tiny legs?' There was a pause while whoever was at the other end digested this piece of information. Then I heard Hilda say, 'all right then, I'll try and get him in the car but if that doesn't work l'm getting an ambulance.'

She put the phone down and, looking down at me, asked if I wanted some breakfast? There was some of my usual cereal spilled on the floor but strangely enough I was much more attracted by some wonderful smells coming from the waste bin. Hilda tipped the contents out onto a piece of newspaper for me. There were some old cabbage leaves, a bit of mouldy cheese and some scraps from last night's supper. I think it was the most delicious meal I ever tasted. After that, with Hilda's help I managed to get into the back of the car, not without a few bruises to my legs and carapace. As we drove along I was able to look out of the window. A few of our neighbours were about, but fortunately no one recognised me. When we reached the surgery Hilda took me in the back way to avoid unwanted attention as she put it. She told me she wanted me to stay in the delivery and storage area where my appearance wouldn't alarm anyone until she could find one of the doctors. But this didn't work because along came young Dawn the receptionist who looked at me with saucer eyes and said, 'Ooh Mrs Gland whatever have you got there? Is it a pet?' 'No, it is not,' said Hilda, huffily, 'it's my Norman, or at least it used be. He's not well at all. Not himself. Get me a doctor, love, quickly, I've got to sort this out.'

Dawn led us into Dr Teacher's room. He was just enjoying an apple in between patients. But when he saw me he gave a convulsive start and the apple went flying across the room, missing my back by inches. 'Mrs Gland,' he cried, 'what has happened? Can this creature be your husband? I tried to explain to him but only succeeded in snapping my jaws noisily. He quickly got on the phone to summon his colleagues. $\mathrm{Dr}$ Brenda and Dr Greengage came rushing in and even old Grimes came in to see what the fuss was about. They questioned Hilda, they prodded me cautiously. Dr Brenda was the least squeamish: she even gave my carapace a soothing stroke. Then they had a conference. There were several theories as to the aetiology of my condition. At any other time I would have found it very interesting and joined in the discussion, but my new jaws were not designed for speech. Dr Brenda thought it might be an endocrine disturbance caused by a massive hormonal upheaval, possibly associated with the male menopause. Dr Teacher suggested that the syndrome might have begun with infection by an insect-borne virus. Then, he reasoned, as a result of a radiation burst (from electricity cables or outer space), the virus had swapped some of the insect's DNA with mine and turned me into an arthropod. Like that Cronenberg movie, with Jeff Goldblum, he said (he's something of a film buff) what was it called - The Fly ?' But the others weren't convinced. Young $\mathrm{Dr}$ Greengage was in favour of doing a whole range of blood tests; if nurse Sarah could find a vein.

Dr Grimes, sceptical as ever, said that in his opinion, the whole thing was a psychotic disorder and I was simply deluding myself into the belief that I was an insect. I should be given some risperidone he said dryly. Or an injection of clopenthixol? And I think they might even have done it if it hadn't been for Dr Greengage who pointed out that if that were the case they were all suffering from the same delusion and we would all need to be injected. Finally they decided that an outpatient referral would be the best course of action. But should it be endocrinology, infectious diseases, or psychiatry? Or even dermatology? In the end they agreed that endocrinology would be the least inappropriate.

They have a new system now called 
Choose and Book and Hilda was told she would have a choice of four different hospitals (of course they didn't even attempt to consult me). Dr Greengage fed my details into the computer which took a little time to respond. Finally it turned out that there was a 3-month waiting list for any of the appointments. Hilda's reaction to this news was one of unaccustomed violence.

'I can't live with that thing for 3 months!' she said, pointing accusingly at me. 'Can't you just send for the pest control people and get rid of it?' Well I know this has all been very stressful for her, but really, what a thing to say. I think everyone was rather shocked. Then Dr Teacher said that Hilda's remark had given him an idea. He rummaged in the bottom drawer of his cupboard and came up with a large silver canister covered with strange black writing. 'Stand back everyone', he roared, as if about to do advanced resuscitation with a defibrillator. Then he pointed the canister at me and squeezed it. A jet of yellow vapour hit me full in the face and made me choke. I was blinded by the fumes and I thought I was going to die. Then the mist cleared and I found I was lying stretched out on the floor - but my human shape had been restored!

Dr Teacher explained to everyone that he had been given the canister by an old rabbi whom he had met at a medical humanities conference in Prague. Many times he had nearly thrown it away but something had always told him that it might come in useful one day. On the way home in the car Hilda and I were both silent until we turned into Chestnut Drive. Then, to my astonishment, she said, 'If you ever do that again l'm leaving you. Aren't you even going to apologise?'

I tried to explain that the transformation had been completely outside my control and was no way something I would wish to repeat. And I greatly regretted the distress it had caused her. She was somewhat mollified by my words and we agreed that the matter was now closed. I think that, provided nothing happens to me tonight, I will bring her a cup of tea in bed in the morning.

\section{One of my heroes: Joe Porter}

His transport as a medical officer in the first world war was a horse - in old age it was a fast car. As one of the eight doctors in Levenshulme in 1955 - four single handed and two partnerships of two, I remember it well. Our administrative body was called the Executive Council and Joe was their nightmare. He rarely replied to official correspondence and was repeatedly fined for not fulfilling his statutory obligations. He even failed to notify his acceptance of new patients - and was never paid for looking after them.

But his patients loved him - despite his wife!

Joe lived and practised in a semidetached Victorian house. His surgery was in the cellar approached down a slope at the side of the house. Unfortunately, Joe's wife was a retired matron whose character lived up to the cartoon image of ferocity then in fashion. She refused to open the waiting room door one second before time, so patients had to queue outside in every weather in a line that went under the kitchen window through which old Mrs Porter would throw her kitchen slops, So, sunshine or rain, patients queued under umbrellas.

Even after 2 years I hardly knew Joe, so I was surprised when one day his wife ordered me to his bedside. I found him in a simple bed with grey blankets in a poorly decorated room. It was only later on that I learnt of his lack of interest in wealth and possessions. I diagnosed congestive cardiac failure and recommended hospitalisation. Very reluctantly he agreed. Perhaps the thought of being nursed by his wife tipped his decision. I said I would look after his patients and he shouldn't worry. There was no question of him paying me. It was how medical etiquette worked in those days. And while he was in hospital I learnt what kind of doctor Joe was. One patient told me that, before the NHS when patients had to pay, he went to $\mathrm{Dr}$ Porter and said he couldn't afford anything that week. 'Never mind,' Joe said, and pulling half a crown from his waistcoat pocket, gave it to the patient saying - 'I think you need this more than I do.' I heard this story many times. Another patient told me that when he developed lobar pneumonia, $\mathrm{Dr}$ Porter went down on his knees by the bedside with the family and prayed that, on the fifth day when there would be a crisis, God would take into account all the good things this man had done. 'He gave me the will to live,' the patient said. 'He made me want to fight.' I soon realised that Joe did with words what I tried to do with diazepam - and Joe did it far better.

Soon after he died, one of Joe's patients came to my surgery. He was an older man, gentle, cap in hand across his chest, tears rolling down his face as he said - 'The doctor's dead. What shall I do?'

Joe is one of my heroes because he cared so deeply. Every patient was special. He understood them. He knew that what he called a symptom might mean one thing to him but something else to the patient. He treated illness as a family affair because incapacity in one person upsets the equilibrium of the family. If he didn't know what was wrong with someone, he'd move heaven and earth to find someone who did. He delivered babies and mourned at the grave. He won't go down in medical history as being a great doctor. He didn't discover anything new. He won't be remembered for lecturing to others on how things should be done. He had no 'cases' - only patients. Although he kept up to date with modern treatments, he regarded that as technical help in his role of looking after people in need.

\section{Stanley Jeffs}

DOI: 10.3399/bjgp08X342741 